\title{
A geografia da direita nacionalista em Portugal: contornos de um processo emergente
}

\author{
The geography of the nationalist right in Portugal: \\ outlines of an emerging process
}

\author{
Paulo Miguel Fernandes Madeira [I] \\ Katielle Susane do Nascimento Silva [II] \\ Jorge Silva Macaísta Malheiros [III]
}

\begin{abstract}
Resumo
A emergência da direita nacionalista em Portugal nas eleições legislativas de 2019 é aqui contextualizada nos fenómenos populistas europeus do mesmo tipo nas décadas mais recentes e na geografia do descontentamento que lhes está associada. A análise da territorialização da votação nesse novo partido, o Chega, na escala municipal, apresenta um padrão que não se coaduna com o que tem sido a geografia eleitoral em Portugal desde a Revolução Democrática de 1974, sugerindo as correlações com um conjunto alargado de variáveis com uma forte motivação identitária da sua base eleitoral, que aparece associada a alguns elementos de desvantagem social e económica. Simultaneamente, a sociologia dos eleitores do Chega apresenta alguns aspetos surpreendentes em face do que se sabe para a generalidade dos casos europeus.
\end{abstract}

Palavras-chave: geografia eleitoral; geografia do descontentamento; Portugal; direita nacionalista; populismo europeu.

\begin{abstract}
The emergence of the nationalist right in Portugal in the legislative elections of 2019 is contextualized here in the framework of similar populist phenomena that have emerged in Europe in recent decades and in the geography of discontent associated with them. An analysis of the territorialization of the votes for this new party, named "Chega" (Enough), at the municipal level presents a pattern that does not match what electoral geography has been in Portugal since the 1974 democratic revolution. The correlations with a wide range of variables point to base voters associated with some elements of social and economic disadvantage and strongly motivated by identity issues. At the same time, the sociology of Chega voters presents some surprising aspects when compared to what is known about most European cases.
\end{abstract}

Keywords: electoral geography; geography of discontent; Portugal; nationalist right; European populism. 


\section{Introdução}

No início do século XXI, começou a tornar-se evidente, na Europa, que a contestação ao regime político-económico vigente estava a deixar de ser um fenómeno lateral, circunscrito às franjas ou a pequenos partidos do sistema político-eleitoral, tornando-se cada vez mais importante. Esse processo assentou em partidos de esquerda e em partidos de direita, com base em ressentimentos nem sempre fáceis de identificar.

A contestação à esquerda tem-se dirigido, tradicionalmente, às injustiças socioeconómicas associadas ao capitalismo em geral e, nas últimas décadas, ao neoliberalismo em particular, a que se juntou uma progressiva preocupação com as formas de subordinação baseadas em elementos identitários diversos (e.g. género, etnia, orientação sexual). Apesar dos progressos no sentido de maior igualdade de princípios e das propostas altermundialistas, essa contestação de esquerda não tem sido capaz de pôr em causa a arquitetura do sistema de economia política internacional em que o globalismo assenta e no qual se articulam as formações predatórias (Sassen, 2014, p. 13) que asseguram a concentração de riqueza no topo da pirâmide de rendimentos e que permitem o funcionamento do sistema global.

No que respeita à direita, é identificado um discurso que contesta aquela arquitetura, ou pelo menos parte dela, sobretudo se se tratar de uma direita com características mais nacionalistas, por vezes fascizantes. Essa contestação é, por isso mesmo, muito feita em nome de questões ligadas à soberania e à cultura e à identidade nacionais, normalmente assumidas de uma forma estática e monolítica, embora também seja associada a aspetos socioeconómicos, enfatizando as consequências negativas da globalização sobre o emprego e rendimentos de vastos setores das populações de muitos países europeus, por vezes com uma agenda económica tipicamente de esquerda (Gordon, 2018, p. 95).

Foi sobretudo essa direita que recentemente teve mais sucesso junto aos eleitores, particularmente os perdedores da globalização, conseguindo crescer consistentemente nos países europeus mais avançados e, também, em muitos dos periféricos, dos quais Portugal é um exemplo, ainda que até agora pouco expressivo.

Os partidos da nova direita nacionalista e antissistémica têm conseguido obter apoio sobretudo entre eleitores brancos mais idosos, de classe trabalhadora, com baixos rendimentos e poucas qualificações, que, por isso, têm mais dificuldade em prosperar na atual economia europeia, de acordo com vários estudos sobre esse fenómeno (Dijkstra, Poelman e Rodríguez-Pose, 2019; McCann, 2019; Gordon, 2018; Guilluy, 2014). Os eleitores com essas caraterísticas são as pessoas comuns, o cidadão da rua, que estão entre quem mais tem perdido com a evolução da economia europeia nas últimas décadas, caraterizada por uma crescente desindustrialização em muitas regiões e países e pelo aumento do peso do setor dos serviços. Em Portugal, até recentemente, o voto antissistema e/ou populista com dimensão significativa e representação parlamentar era de esquerda, como veremos mais detalhadamente adiante, mas, nas eleições legislativas de 2019, um partido de direita com um discurso e propostas políticas que podem ser enquadradas na direita nacionalista e populista, o 
Chega, apresentou-se pela primeira vez a votos e conseguiu eleger um deputado à Assembleia da República, André Ventura, seu fundador. No seu manifesto político, o Chega é apresentado como "um partido nacional, conservador, liberal e personalista" (Chega, s/d).

No contexto de reconfiguração recente do quadro político-eleitoral europeu, em que partidos com essas condições têm ganho peso e, nalguns casos, colocado em risco a hegemonia das forças tradicionais, a eleição em Portugal de um deputado por um partido com essas caraterísticas, ${ }^{1}$ logo quando se apresentou pela primeira vez em eleições para a Assembleia da República, reveste-se de particular significado. Por isso, é importante perceber as bases desse seu primeiro sucesso eleitoral. Posteriormente, nas eleições legislativas na Região Autónoma dos Açores, em 2020, o partido foi o quarto mais votado, com um pouco mais de cinco por cento dos votos, tendo conseguido eleger dois deputados regionais. ${ }^{2}$

Esse resultado permitiu que o Chega negociasse dar apoio parlamentar a um governo de coligação liderado pelo segundo partido mais votado (o Partido-Social Democrata, de centro-direita), afastando, assim, do Governo Regional o Partido Socialista (de centro-esquerda), que foi o mais votado, mas não alcançou maioria absoluta de deputados. Ainda mais recentemente, o líder do partido, André Ventura, candidatou-se às eleições presidenciais de 24 de janeiro de 2020, tendo ficado em terceiro lugar (entre sete candidatos) e obtido cerca de meio milhão de votos (11,9\%), o que confirmou o processo de crescimento em curso. Regressando à esfera partidária, várias sondagens, realizadas em 2020 e no início de
2021, têm colocado a votação no Chega acima dos $5 \%$ em novas eleições legislativas, por vezes a aproximar-se dos $10 \%$, resultado que o colocaria como um dos três ou quatro maiores partidos portugueses. Tendo isto em consideração, esta investigação visa contribuir para a compreensão da geografia desse fenómeno em Portugal, discutindo os factores que estão na base dos padrões detetados.

Nesse quadro, o objetivo a que nos propomos é analisar os resultados eleitorais do partido Chega nas eleições legislativas de 2019, numa perspetiva geográfica, com o intuito de (1) perceber a origem político-partidária dos seus votantes; (2) analisar as suas principais caraterísticas socioeconómicas, considerando dinâmicas de transformação territoriais de curto prazo; e (3) identificar as eventuais semelhanças e diferenças com os eleitores que têm apoiado partidos e movimentos desse tipo noutros países europeus.

Para cumprir esses desideratos, foram analisadas variáveis de natureza eleitoral, social e económica, com recurso a análises estatísticas de correlação linear e de regressão linear múltipla. Os dados utilizados foram obtidos no Instituto Nacional de Estatística (INE), Alto Comissariado para as Migrações (ACM), Ministério da Administração Interna (MAI) e Serviço de Estrangeiro e Fronteiras (SEF). O período escolhido para análise vai de 2015 a 2019, anos das duas últimas eleições legislativas em Portugal. Contudo, algumas variáveis sociais e económicas estruturais são de 2011, ano do último censo em Portugal. Essas diferenças temporais colocaram desafios à investigação, contudo não inviabilizaram a análise. 


\section{Ascensão da direita nacionalista, populismo e "lugares que não importam" na Europa}

\section{O avanço dos movimentos \\ antissistema na Europa}

O primeiro grande marco da contestação ao regime político-económico vigente na Europa aconteceu em 2005, com duas derrotas eleitorais dos partidos centrais do sistema, quando o Tratado Constitucional Europeu, que preconizava uma constituição para a União Europeia, foi recusado em referendo em França (com $54,67 \%$ de votos contra) e nos Países Baixos (com $61,54 \%$ de votos contra). É certo que a contestação ao sistema já vinha de trás, quer à esquerda quer à direita, embora os partidos de extrema direita, comparativamente com a extrema esquerda, tenham tido historicamente votações menos expressivas. 0 primeiro sucesso eleitoral da atual direita antissistema talvez tenha sido o da Frente Nacional francesa, fundada em 1972 (rebatizada "Rassemblement National" em 2018) e que, em 1984, conseguiu eleger o seu líder, Jean-Marie Le Pen, como deputado ao Parlamento Europeu. Contudo, essa contestação nunca chegara ao ponto de fazer infletir as posições das lideranças da UE, ao contrário do que aconteceu na sequência dos referendos de 2005.

Após a recusa do Tratado Constitucional, outros atos eleitorais marcaram a ascensão, em vários países, de partidos que contestavam a integração na UE, aspetos do sistema socioeconómico e frequentemente o "encoIhimento" da soberania e uma suposta perda de identidade, associando a imigração para a Europa e a presença (mesmo consolidada) de comunidades de imigrantes e seus descendentes a diversos desses processos. A manutenção do Fidesz no poder na Hungria desde 2010, com Viktor Orbán como primeiro-ministro, é um exemplo do sucesso dessa direita nacionalista e identitária, algo autoritária, misturada com algum ceticismo ante a UE. Na Polónia, esse fenómeno tem sido protagonizado pelo partido Lei e Justiça (PiS).

0 ano de 2016 foi um ponto de viragem importante, com a vitória do "não" no referendo sobre a permanência do Reino Unido na União Europeia e com a eleição de Donald Trump para presidente dos Estados Unidos, num fenómeno que se enquadra claramente no que temos vindo a descrever. Este último, pela influência dos Estados Unidos, deu novo alento aos movimentos desse tipo na Europa. Nas eleições presidenciais austríacas de 2016 e nas francesas de 2017, candidatos da direita nacionalista ficaram em segundo; e na Alemanha, também em 2017, a ascensão da AfD (Alternative für Deutschland) nas eleições legislativas tornou difícil organizar uma maioria de suporte a um novo governo.

O populismo e o seu sucesso recente na direita

Esse fenómeno ancorado sobretudo à direita, em que novos partidos políticos adotam um discurso insurgente contra as forças hegemónicas no sistema sociopolítico, que se centra nas preocupações de grande parte das classes populares europeias e frequentemente adota uma linguagem simplista e superficial nas suas mensagens, tem sido designado como "populismo". Na verdade, o conceito de populismo não é claro, sendo objeto de controvérsia dentro da ciência política (Lisi, 2019; Dijkstra, Poelman e Rodríguez-Pose, 2019, pp. 3-4; 
Gordon, 2018, p. 97; Mudde, 2004, p. 541). A definição que parece mais aceite é a que vê os partidos populistas como estabelecendo uma dicotomia entre o povo e uma elite supostamente egoísta e distante do resto da população, por vezes corrupta, criando, assim, uma dicotomia entre um "nós", o povo, e um "eles", os dirigentes, vistos como inimigos das pessoas comuns (Bonikowski, 2017; Mudde, 2004). Outra definição possível é a que vê o populismo como a rejeição da autoridade moral e intelectual da classe dirigente, substituindo-a pelas respostas de senso comum das classes populares (Gordon, 2018, pp. 97).

O populismo pode ser visto como uma ideologia, como acontece com Mudde (2004), mas também isso pode ser controverso. Pode ser ainda considerado uma forma de mobilização política ou um quadro discursivo (Bonikowski, 2017), ou apenas uma "lógica política - um modo de pensar sobre a política" (Judis, 2016, p. 14). A definição do populismo como a transposição para o plano partidário da oposição entre dois polos - o povo e uma elite - foi ampliada por Judis (ibid.), que the acrescenta um tipo de populismo que opõe o povo também a um terceiro grupo, que, nas sociedades ocidentais, podem ser imigrantes, minorias étnicas ou religiosas. Este é um populismo que categoriza a sociedade em três grupos e, por isso, designado como "triádico". Se os populismos de esquerda tendem a defender o povo contra a elite, numa perspetiva vertical, podendo, assim, ser designados como diádicos, os populismos de direita, nomeadamente da direita nacionalista europeia contemporânea, além dessa oposição, tendem a incorporar também a oposição entre o povo e os outros grupos considerados exteriores à sociedade supostamente tradicional e nacional originária, que são mesmo vistos como uma ameaça para esta.

A oposição entre "povo" e "elite", ou entre "povo" e "classe dirigente", pode invocar diferentes grupos e/ou poderes concretos, como, por exemplo, grupos étnicos ou socioeconómicos, Wall Street e a finança internacional, as elites tecnocráticas europeias (Freire, 2019a); note-se que algumas das oposições estabelecidas remetem para questões de direita, outras evocam questões de esquerda. Isto permite compreender que Mudde e Kaltwasser (2017, pp. 5-6) classifiquem o populismo como "uma ideologia ténue" ${ }^{3}$ ou "uma ideologia de baixa densidade" (expressão preferida pelo cientista político português André Freire).

Essa falta de densidade ideológico-programática do populismo implica que ele não forneça, à partida, soluções complexas e abrangentes para as questões políticas importantes e que, por isso, surja quase sempre associado a outros conceitos e elementos ideológicos. Sendo assim, o populismo pode assumir formas programáticas muito diferentes. Um exemplo desse polimorfismo é a ideia, proposta por Mouffe (2018), de um populismo para renovação da esquerda, contra a hegemonia neoliberal e compatível com a democracia liberal. Aqui, o populismo é visto como uma forma de fazer política e não como uma ideologia (Freire, 2019b).

Para que as ideias populistas adquiram relevância político-eleitoral, é necessária a existência de movimentos políticos que as promovam e se proponham a eleições e que uma parte substancial do eleitorado esteja disposta a aceitá-las e a votar nelas. Um desses elementos pode preceder o outro em maior ou menor 
grau, sendo possível que eles se retroalimentem - haver alguma predisposição para esse populismo entre o eleitorado pode levar ao surgimento de partidos que o apoiem, o que, por sua vez, pela amplificação dessas ideias no espaço público, poderá fazer com que a sua base eleitoral se alargue.

Os partidos populistas que foram surgindo, ou que a partir de dado momento cresceram rapidamente, fizeram-no por vezes com base em políticos empreendedores (Gordon, 2018, p. 98) que se mobilizaram expressamente para atrair o voto do descontentamento popular que sentiam existir na sociedade e a que os partidos tradicionais do sistema não davam resposta. $E$ as razões desse descontentamento popular têm sido frequentemente atribuídas ao desinteresse das classes dirigentes pelo que acontece ao povo. Por vezes, parece existir uma abordagem de tipo empresarial, em que um conjunto de políticos decide dar corpo ao descontentamento popular, como se de uma oportunidade de mercado se tratasse.

\section{Razões da adesão dos eleitores}

A adesão a essas ideias parece assentar em duas ordens de razões, refletidas no discurso eleitoral que tem sido bem-sucedido. Por um lado, dificuldades económicas crescentes, com perda de rendimentos e até de emprego, têm vindo a afetar parte substancial da população (Dijkstra, Poelman e Rodríguez-Pose, 2019; Ferrão, 2019), sem perspetivas de que a situação seja revertida no atual contexto. Por outro lado, muitas pessoas sentem-se esquecidas ou mesmo marginalizadas e ameaçadas do ponto de vista político, cultural e até identitário, sobretudo quando as dificuldades económicas coexistem com fortes correntes migratórias, quer de saída de população local em busca de oportunidades de trabalho, quer de entrada de população estrangeira, que por vezes ocorrem em simultâneo. Isto gera um receio ou mesmo um sentimento de perda de identidade, que pode ser reforçado pela agenda pós-materialista de parte das populações metropolitanas.

Essa transformação tem estado muito ligada à globalização neoliberal, que conduziu a uma grande abertura das economias europeias ao comércio internacional e ao investimento e circulação de capitais. Isto induziu um grande crescimento da importação de bens agrícolas e industriais baratos, neste último caso sobretudo da Ásia, e permitiu que uma parte importante dos grupos industriais europeus passasse a produzir, na Ásia, o que antes produzia e vendia (e continue a vender) na Europa e que, por vezes, também exportava. Obviamente, isto reduziu drasticamente o emprego industrial na Europa, afetando principalmente pessoas da classe trabalhadora com menos qualificações e mais velhas, que, na Europa, são em grande maioria branca e estão entre os que têm sido designados como "perdedores da globalização" nos países desenvolvidos do Ocidente.

Se a internacionalização dos mercados de bens e de capital foi mais intensa do que a dos mercados de trabalho, esta também é essencial para garantir o lucro e a competitividade dos setores económicos, apoiando-se na segmentação da mão-de-obra (em função do género, da etnia, da origem geográfica) e na redução dos seus custos. Se os imigrantes mais qualificados são essenciais para assegurar a criatividade e a inovação em sectores como a I\&D ou as telecomunicações nos países desenvolvidos da Europa, os de menor qualificação 
garantem suprimentos de trabalho em setores de limitada transferibilidade geográfica, marcados pela sazonalidade ou pela forte suscetibilidade a crises conjunturais (e.g. agricultura, construção civil e obras públicas, hotelaria) (Malheiros, 2012). Nesse quadro, o recrutamento de estrangeiros torna-se francamente apetecível e incrementa a concorrência em relação aos trabalhadores nacionais, ajudando a alimentar o discurso anti-imigrante que atribui, aos primeiros - e não às condições do sistema económico e aos empregadores -, a responsabilidade pelo deteriorar das condições dos segundos.

Mas a votação em partidos nacionalistas de direita na Europa tem sido associada também a questões de atitude da parte dos eleitores relativamente a um conjunto de valores relacionados com atitudes ante os imigrantes, o multiculturalismo, a autoridade, a desconfiança em face da governação nacional e internacional, muitas vezes sem relação explícita com a insegurança económica (Inglehart e Norris, 2016, apud Gordon, 2018, p. 98). Trata-se de pessoas que tendem a ver os seus valores e sentimentos de identidade ameaçados pela partilha dos seus espaços quotidianos com comunidades imigrantes culturalmente diferentes, sobretudo as islâmicas, principalmente quando o crescimento destas últimas é recente e rápido (Ferrão, 2019, pp. 62-63) e os sentimentos de perda económica e social se acentuam.

Nalgumas regiões, isto diluiu o sentimento de se viver num Estado-nação homogéneo com valores e identidades próprias e falsamente estáticas, gerando uma reação forte por parte de certos segmentos da população. A direita populista não só tira partido desses sentimentos, como os alimenta, contrariando o consenso social-liberal e de aceitação da diversidade cultural dos partidos que têm sido dominantes.

Para Fukuyama (2019), as dimensões económica e nacionalista têm sido combinadas pelo populismo de direita, que tem conseguido aproveitar-se do ressentimento de uma classe trabalhadora que tem perdido postos de trabalho em virtude, por exemplo, da subcontratação e da competição com populações estrangeiras no seio do capitalismo globalizado, para reforçar nacionalismos. Desse modo, o ressentimento acaba por deslocar-se dos efeitos do capitalismo para a população estrangeira, disseminando discursos assentes na identidade nacional e, por vezes, discursos de ódio.

Assim, o voto populista (sobretudo de direita) constitui também uma recusa cultural dessa agenda pós-materialista, mas que tem fortes consequências materiais para os europeus das classes sociais mais frágeis, quer em termos de rendimentos, quer do ambiente sociocultural em que passaram a estar territorialmente inseridos. Aliás, Gordon (2018, p. 109) encontrou uma relação entre imigração recente e apoio populista em trabalhadores de pequenos estabelecimentos; e entre mudanças de longo prazo na composição da população e apoio a partidos populistas por residentes de longo prazo nas regiões afetadas. Essas pessoas são "localistas que vêm no território, nos seus territórios, nos lugares onde habitam, a última âncora do capital social e da sociabilidade que lhes resta e da segurança a que aspiram" (Ferrão, 2019, p. 63). 
A revolta dos "lugares que não importam" e a geografia do ressentimento

Vários geógrafos têm estudado os fenómenos de insurgência eleitoral, quer no âmbito do voto populista quer no âmbito do voto anti-União Europeia (que em parte é coincidente com o populista, mas não totalmente), tendo chegado à conclusão de que, frequentemente, esse tipo de eleitorado está mais concentrado nuns locais do que noutros, o que deu origem a uma nova geografia, a geografia do descontentamento ou do ressentimento - a expressão adotada neste número dos Cadernos Metrópole. 0 que esses locais têm em comum é serem áreas pobres ou em declínio, muitas vezes negligenciadas durante muito tempo pelo poder político, ao ponto de este lhes ter feito sentir que são "lugares que não importam" - a expressão usada por Rodríguez-Pose (2018) - do ponto de vista do desenvolvimento económico e social.

A globalização neoliberal teve como consequência, na Europa e não só, o reforço de algumas forças que atuam no sentido da divergência de desenvolvimento socioeconómico à escala regional, sobretudo através do comércio internacional (Madeira, 2019), tendo havido, em termos gerais, um reforço dos grandes centros metropolitanos e declínio (relativo ou absoluto) das regiões mais periféricas.

Na Europa Ocidental, esses problemas afetam, sobretudo, regiões de pequenas e médias cidades industriais, que têm sofrido um declínio do emprego ou do rendimento, e também os seus subúrbios e áreas rurais circundantes, em que os rendimentos estagnaram (Martin et al., 2018, p. 9). Isto está associado a uma combinação de diminuição do rendimento por habitante em face das médias nacionais, perda de empregos e diminuição da força de trabalho.
Parte dessas regiões já foram prósperas, e a realidade de declínio (absoluto ou relativo) das últimas décadas pode dar às suas populações uma sensação acrescida de perda, em relação às áreas que sempre estiveram abaixo do rendimento médio e/ou em perda de emprego. Esses lugares que não importam, ou "lugares que não contam" (Ferrão, 2019), ficaram nessa situação não apenas devido às dinâmicas induzidas pela globalização neoliberal, mas também pela ausência de políticas de desenvolvimento regional suficientemente fortes para as contrariar (Madeira, 2019).

Os eleitores desses lugares começaram a revoltar-se nas urnas de voto, tendo esse fenómeno assumido dimensões crescentes, como acima referido, ao ponto de pôr em causa a ordem político-económica que tem prevalecido nas últimas quatro décadas. É aquilo a que Rodríguez-Pose (2018) chamou "a vingança dos lugares que não importam" contra o sentimento de serem deixados para trás.

As causas destas revoltas eleitorais estão já identificadas genericamente para a Europa, havendo obras desenvolvidas com detalhe para casos nacionais, como, por exemplo, o francês e o britânico, confirmando, no essencial, essas tendências. Na França, o aumento das desigualdades decorrente do neoliberalismo globalista conduziu a uma fratura social entre classes populares mais localistas e elites mundializadas, com opções eleitorais tendencialmente distintas (Guilluy, 2014). No Reino Unido, essas revoltas eleitorais têm-se concentrado muito em territórios que têm sofrido declínios prolongados (McCann, 2016). Isto tornou-se evidente nos padrões territoriais dos votos pela permanência e pela saída do Reino Unido da União Europeia, no referendo de 2016. 


\section{Metodologia}

A investigação desenvolvida neste artigo assenta na escala municipal portuguesa, ${ }^{4}$ apoiando-se a análise desenvolvida em elementos europeus e nacionais, cujo pano de fundo se pode encontrar no quadro mundial do neoliberalismo globalista. A discussão mais abrangente focada na Europa teve como base explicitar as caraterísticas e evidências da ascensão de um nacionalismo de direta, de modo a ajudar a compreender a emergência recente desse fenómeno em Portugal, claramente ampliado pela chegada, à Assembleia da República, de um deputado do partido Chega nas eleições de 2019.

A informação relativa à análise do caso dos municípios portugueses assenta num conjunto de dados secundários de natureza quantitativa provenientes do Instituto Nacional de Estatística (INE), Alto Comissariado para as Migrações (ACM), Ministério da Administração Interna (MAI) e Serviço de Estrangeiros e Fronteiras (SEF). Parte desses dados foi obtida no portal Pordata, no qual tais dados se encontram organizados e tratados. 0 recorte temporal vai de 2001 a 2019, dada a diversidade das variáveis escolhidas nas três dimensões definidas: eleitoral, sociodemográfica e económica. O racional de escolha da temporalidade das várias variáveis teve como base a obtenção da informação mais recente disponível (retrato da situação atual), conjugada com dados de um momento anterior relativamente próximo (para a obtenção de dinâmicas e tendências de transformação muito recentes). Daqui resultou a consideração de dados das duas últimas eleições legislativas em Portugal (2015 e 2019), dos dois últimos Censos da População (2001 e
2011) e de algumas variáveis sociais, demográficas e económicas para outros anos situados entre 2009/2010 e 2019 (Quadro 1).

Para as análises de enquadramento e suporte destinadas a perceber a evolução eleitoral nacional, foram consideradas as duas décadas do presente século, abrangendo as seis últimas eleições legislativas - 2002, 2005, 2009, 2011, 2015 e 2019. As variáveis incluídas nas dimensões sociodemográficas e económicas têm como propósito ajudar a explicar o padrão geográfico municipal da votação no Chega, em 2019, de algum modo interpretada como uma "geografia do descontentamento". A sua escolha partiu dos elementos discutidos na seç̧ão precedente e considerou indicadores que estão em linha com aqueles que na Europa têm sido mais associados ao processo aqui analisado.

Evidentemente, esses indicadores foram adaptados à situação específica de Portugal, não só devido à natureza da informação disponível, mas também de forma a considerarem aspetos sociais e económicos particulares. Sublinhamos, como exemplo, a escolha da variável população cigana residente em Portugal (Mendes, Magano e Candeias, 2014), tendo em vista que o discurso do deputado eleito do Chega se aproveitou de um secular preconceito sofrido por essa população para construir uma narrativa eleitoral que reforçava estereótipos contra ela, sendo relevante perceber eventuais efeitos desse processo. 0 cálculo para a população cigana teve por base uma amostra de 113 concelhos $^{5}$ em Portugal Continental, uma vez que não existe informação disponível para o restante.

O conjunto dos 52 indicadores de caracterização e dinâmica de curta duração (taxas de variação) foi submetido a duas análises 
Quadro 1 - Variáveis utilizadas na correlação e regressão múltipla

\begin{tabular}{|c|c|c|}
\hline Dimensões & Variáveis & Ano \\
\hline \multirow{3}{*}{ Eleitoral } & $\%$ de votos válidos Chega & 2019 \\
\hline & \% e Tx de variação de votos válidos (PS, PSD*, PCP**, PNR, CDS*, IL, PAN e BE) & 2015-2019 \\
\hline & \% e Tx de variação de abstenção & 2015-2019 \\
\hline \multirow{17}{*}{ Sociodemográfica } & \% População residente cigana*** & 2014 \\
\hline & \% População feminina & 2011 \\
\hline & $\%$ Indivíduos Analfabetos**** & 2011 \\
\hline & \% Indivíduos com até o 9 ano & 2011 \\
\hline & \% Indivíduos com ensino secundário & 2011 \\
\hline & \% Indivíduos com ensino superior & 2011 \\
\hline & $\%$ Indivíduos analfabetos e com até o 9 ano & 2011 \\
\hline & \% População residente jovem (15 - 29 anos) & 2011 \\
\hline & \% População residente adulta (30 - 64 anos) & 2011 \\
\hline & \% População residente idosa (65 e mais anos) & 2011 \\
\hline & \% População estrangeira & 2019 \\
\hline & \% População estrangeira extracomunitária & 2019 \\
\hline & Tx de variação População estrangeira & 2010-2019 \\
\hline & Tx de variação População estrangeira extracomunitária & 2010-2019 \\
\hline & Tx de variação população residente total & 2001-2011 e 2009-2019 \\
\hline & Índice de envelhecimento & 2001, 2011, 2015 e 2019 \\
\hline & Tx de variação do índice de envelhecimento & 2015-2019 e 2011-2019 \\
\hline \multirow{9}{*}{ Económica } & \% População empregada setor secundário & 2001 e 2011 \\
\hline & $\%$ Desempregados***** & 2011, 2015 e 2019 \\
\hline & \% (número índice) Poder de compra per capita & 2017 \\
\hline & Beneficiários e \% Beneficiários(as) do Rendimento Social de Inserção & 2015 e 2019 \\
\hline & \% População empregada & 2001 e 2011 \\
\hline & Tx de variação desempregados & 2011-2015 e 2015-2019 \\
\hline & Tx de variação Beneficiários(as) do Rendimento Social de Inserção & 2015-2019 \\
\hline & Tx de variação população empregada & 2001-2011 \\
\hline & Tx de variação população empregada no setor secundário & 2001-2011 \\
\hline
\end{tabular}

Fontes: INE, SEF, ACM, MAI.

* Os Partidos PSD e CDS foram às eleições em 2015 enquanto coligação. Desse modo, consideramos os dois partidos juntos para a variação 2015-2019.

** O PCP concorre sob a sigla CDU, em coligação com um pequeno partido ecologista que nunca concorreu isoladamente a eleições.

*** Dado existente apenas para 113 concelhos de Portugal Continental; os concelhos restantes foram excluídos do cálculo dessa correlação que, portanto, inclui apenas 113 unidades de análise.

**** Os dados referentes aos níveis de escolaridade referem-se aos indivíduos com 15 e mais anos.

***** O dado de desemprego engloba apenas os desempregados inscritos nos centros de emprego e de formação profissional, e não a totalidade dos desempregados. 
estatísticas suportadas pelo software IBM SPSS 24: correlação de Pearson e regressão linear múltipla. Embora se tenha executado uma matriz de correlação de todas as variáveis entre si, reteve-se, como processo de análise fundamental, o vetor que inclui a correlação de cada indicador com a percentagem de votos obtida pelo Chega nas eleições legislativas de 2019, considerada como variável dependente. Retiveram-se, para análise, as variáveis com correlação mais elevada (em módulo) e significativa, tomando-se como referência coeficientes de correlação (R) superiores a 0,34.

A análise de correlação foi repetida considerando apenas os 109 concelhos da metade sul de Portugal, dada a relevância de uma análise que considerasse, complementarmente ao conjunto nacional, apenas os concelhos pertencentes a sete distritos localizados nessa área (Lisboa, Santarém, Portalegre, Évora, Setúbal, Beja e Faro), em virtude da sobrerrepresentação de votos no Chega aqui detetada. A mesma análise foi realizada para a população residente cigana, sendo considerados apenas os 47 concelhos que dispunham dessa informação nesse recorte territorial.

Posteriormente, as variáveis foram submetidas a um modelo de regressão múltipla em que a percentagem de votos do Chega nas eleições de 2019 continuou a funcionar como variável dependente, e todas as restantes variáveis eleitorais, sociodemográficas e económicas juntas como independentes. Esse modelo, que permite aferir como determinados conjuntos de variáveis independentes (mais significativas) se conjugam para "explicar" a variável dependente, foi reproduzido para o conjunto dos municípios do sul.
A cartografia dos resultados eleitorais do Chega representa os Quocientes de Localização $(\mathrm{QL})^{6}$ municipais, o que permite verificar a sobre e sub-representação dos resultados desse partido por concelho, em face da média nacional (1,3\% dos votos). A espacialização dos QLS foi suportada pelo software ArcGIS 10.6.

A escolha da estratégia metodológica de análise de dados agregados (na ciência política também conhecida por "metodologia ecológica" ou "análise ecológica"), aqui adotada para a análise estatística, resulta de ser a única simultaneamente possível e exequível para alcançar os objetivos a que nos propusemos. Uma eventual recolha de dados individuais por inquérito sobre os eleitores do Chega em 2019 exigiria uma grande quantidade de meios; adicionalmente, seria muito incerto que, se contatados por inquiridores, esses eleitores aceitassem revelar o seu voto e fossem totalmente sinceros quanto às respetivas motivações.

Assim, são utilizados dados individuais agregados territorialmente, correlacionados com a votação no Chega nas legislativas de 2019, que foi também utilizada como variável dependente numa regressão múltipla. Esses procedimentos estão envolvidos na discussão sobre a "falácia ecológica" (Freire, 2001, pp. 33-43; King, 1997, pp. 3-34), cujos riscos nesses casos são respetivamente de correlações espúrias e de colinearidade entre variáveis. As correlações significativas retidas para análise $(R>0,34)$ não revelaram sinais desse problema, e a matriz de correlação de todas as variáveis independentes apontou também para colinearidades não muito significativas na maioria dos casos. De resto, é sabido que, na maioria das análises em ciências sociais e geografia, é comum existir algum grau 
de correlação entre as variáveis que acaba por não afetar os resultados do modelo final, podendo mesmo auxiliar em alguns processos de interpretação.

\section{O Chega no sistema político- -partidário português: o discurso político, os resultados eleitorais e a sua interpretação}

\section{O sistema político-partidário português e a emergência do Chega}

O sistema partidário português permaneceu até recentemente, no essencial, semelhante ao que se constituiu após a Revolução Democrática de abril de 1974, que derrubou o regime fascista do Estado Novo. Em 1975, houve eleições para uma Assembleia Constituinte, que aprovou a Constituição da República do novo regime, e em 1976 decorreram as suas primeiras eleições legislativas. Logo nessas duas eleições, PS e PSD (então PPD, de Partido Popular Democrático) emergiram como os dois principais partidos no país, vindo a consolidar-se como o "centrão" do regime, situação que ainda hoje se mantém. Também, desde 1975-76, PCP e CDS-PP emergiram como o terceiro e quarto partidos, alternadamente, o que se manteve até 2009, quando, pela primeira vez, o Bloco de Esquerda ultrapassou o PCP, que nesse ano foi o quinto partido mais votado.

Até recentemente, a única mudança importante e consistente em relação ao sistema fora o aparecimento do Bloco de Esquerda (BE), em 1999 (ver Quadro 2). Nesse ano, elegeu dois deputados e nas eleições seguintes iniciou uma tendência de crescimento que o colocou na ordem de grandeza do PCP e CDS. Mas, nas eleições legislativas de 2015, o sistema partidário deu sinais importantes de mudança. Nesse ano, um partido animalista-ambientalista elegeu um deputado e, em 2019, conseguiu eleger quatro. Também em 2019, outros três partidos elegeram o seu primeiro deputado no Parlamento, entre os quais o Chega, o que significou uma diversificação significativa das formações políticas representadas.

Em 2015, houve outro aspeto do sistema político-partidário que mudou. Desde a Revolução de 1974, a governação de Portugal esteve nas mãos do PS e do PSD, alternadamente ou coligados, por vezes com o CDS-PP. Este conjunto de partidos era, até então, conhecido como "o arco da governação", por serem os únicos que governaram. Até então, o PS nunca tinha aceitado coligar-se com os partidos à sua esquerda no Parlamento, alimentando, num quadro antagónico ao PCP, uma fratura histórica que remetia para o final do período revolucionário, em 1975. Ademais, a existência de algumas posições vistas como incompatíveis em matérias como os compromissos internacionais de Portugal, as orientações de política económica, a proteção do trabalho ou o nível de intervenção do estado na economia foram impedindo a consecução de eventuais coligações, não só com o PCP, mas também com o BE.

Ora, na sequência das eleições legislativas de 2015, após um período de intensa crise económico-financeira que teve uma resposta austeritária de pendor neoliberal por parte do governo de direita (coligação PSD-CDS), que fez disparar o desemprego, reduzir os salários e diminuir a proteção social, o PS recusou a apoiar um governo minoritário de direita ${ }^{7}$ e negociou, pela primeira vez, o apoio 
Quadro 2 - Partidos políticos com representação parlamentar em 2019

\begin{tabular}{|c|c|c|c|c|}
\hline Partido & Ideologia & $\begin{array}{c}\text { Votação } \\
\text { em } 2019 \\
(\%)\end{array}$ & $\begin{array}{c}\text { № de } \\
\text { deputados } \\
\text { em } 2019\end{array}$ & $\begin{array}{c}\text { Representação } \\
\text { parlamentar } \\
\text { desde }\end{array}$ \\
\hline Chega & Direita Nacionalista e Populista & 1,29 & 1 & 2019 \\
\hline $\begin{array}{l}\text { Partido Nacional } \\
\text { Renovador (PNR)* }\end{array}$ & Direita Nacionalista Conservadora & 0,33 & 0 & $*$ \\
\hline Iniciativa Liberal & $\begin{array}{l}\text { Liberalismo de Direita em todos os } \\
\text { domínios }\end{array}$ & 1,29 & 1 & 2019 \\
\hline CDS-PP & Direita Conservadora - Democracia-cristã & 4,42 & 5 & 1976 \\
\hline $\begin{array}{l}\text { Partido Social } \\
\text { Democrata (PSD) }\end{array}$ & Liberalismo Económico de centro direita & 27,76 & 79 & 1976 \\
\hline $\begin{array}{l}\text { Pessoas, Animais, } \\
\text { Natureza (PAN) }\end{array}$ & $\begin{array}{l}\text { Animalista com tendência ambientalista } \\
\text { e inclinação para a esquerda }\end{array}$ & 3,32 & 4 & 2015 \\
\hline $\begin{array}{l}\text { Partido Socialista } \\
\text { (PS) }\end{array}$ & $\begin{array}{l}\text { Socialismo democrático/ social- } \\
\text { democracia (centro esquerda) }\end{array}$ & 36,34 & 108 & 1976 \\
\hline Livre & $\begin{array}{l}\text { Libertária de Esquerda com tendência } \\
\text { para o socialismo democrático }\end{array}$ & 1,09 & 1 & 2019 \\
\hline $\begin{array}{l}\text { Bloco de Esquerda } \\
\text { (BE) }\end{array}$ & $\begin{array}{l}\text { Libertária de Esquerda com tendência } \\
\text { para o socialismo democrático }\end{array}$ & 9,52 & 19 & 1999 \\
\hline $\begin{array}{l}\text { Partido Comunista } \\
\text { Português (PCP)** }\end{array}$ & Comunismo & 6,33 & 12 & 1976 \\
\hline
\end{tabular}

Fonte: elaborado com base em informação dos sites partidários e do Ministério da Administração Interna (SGMAI, 2019).

* O PNR nunca elegeu deputados à Assembleia da República; foi incluído nesta lista devido à proximidade ideológica com o Chega e porque a correlação da votação desses dois partidos foi maior do que a de qualquer partido com representação parlamentar com o Chega.

** Desde 1987, o PCP concorre a eleições nacionais, coligado com um pequeno partido ecologista, o PEV, que nunca concorreu isoladamente a eleições legislativas.

parlamentar do PCP e do Bloco a um governo minoritário seu, que se propôs reverter, de forma progressiva e mitigada, algumas políticas impostas no quadriénio anterior, por exemplo nos domínios salarial, da proteção social e dos transportes urbanos. Esse facto - a nomeação, pela primeira e única vez na história da democracia lusa, de um primeiro-ministro não pertencente à força política vencedora das eleições, mas com apoio de uma maioria negociada no Parlamento - constitui o terceiro elemento de rutura associado às eleições de 2015 (Freire, 2017).

Na República Portuguesa que saiu da Revolução de 25 de abril de 1974, os eleitores elegem, por sufrágio universal e direto, os deputados que compõem a Assembleia da República (também conhecida por "Parlamento"). Esses deputados são incluídos nas listas dos partidos políticos que concorrem a 
cada eleição, organizadas por círculos eleitorais distritais, ${ }^{8}$ círculos das regiões autónomas dos Açores e da Madeira e da emigração. Cada círculo eleitoral elege um número de deputados determinado em função do seu número de eleitores (exceto na emigração), pelo método proporcional de Hondt.

A emergência recente do Chega e de outros pequenos partidos que entraram na Assembleia da República pode ser vista como o resultado de uma tendência de erosão eleitoral dos partidos centrais no sistema político dos países europeus, que tem sido concomitante à ascensão de partidos de direita nacionalista e de causas temáticas, como o ambientalismo e o animalismo, e por vezes também de partidos de esquerda que contestam a hegemonia neoliberal. Isso traduziu-se, por exemplo, em os partidos socialistas grego e francês terem deixado de ter os seus tradicionais papéis centrais no sistema, passando a atores de segundo plano.

Em Portugal, essa tendência tem-se também manifestado nas eleições legislativas desde o início do século, com o conjunto da votação no PS e no PSD a cair de quase $80 \%$ dos votos válidos, em 2002, para 67,4\% em 2019 (Figura 1).

Note-se que usar os votos válidos como referência se reflete em percentagens mais elevadas do que usar os votantes (que incluem

Figura 1 - A erosão do centro político-partidário em Portugal no início do século XXI

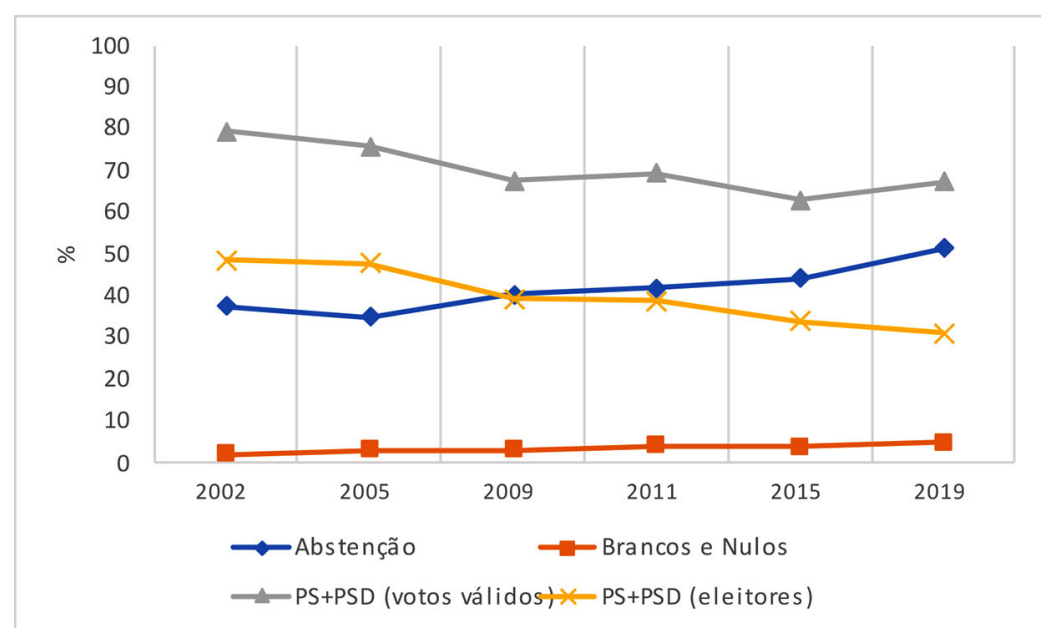

Fonte dos dados: Ministério da Administração Interna (SGMAI, 2019). 
também os votos brancos e nulos) ou os eleitores inscritos. No caso dos votantes, as percentagens reduzem-se dois a três pontos percentuais ante os votos válidos; mas no caso de a referência serem os inscritos, a soma da votação no PS como a do PSD passa a ser de 48,6\% em 2002 e de 31,1\% em 2019.

Nesse contexto, o facto de o Chega se ter apresentado pela primeira vez a votos nas eleições legislativas de 2019 e ter eleito de imediato o seu presidente-fundador, André Ventura, como deputado pelo círculo de Lisboa, reveste-se de particular significado, por se tratar de um partido com um discurso e propostas políticas que podem ser enquadradas na direita nacionalista e populista que tem crescido rapidamente em muitos países europeus. No seu Manifesto Político Fundador (Chega, s/d), o partido assume-se como "nacional, conservador, liberal e personalista"; e, nalgumas sondagens recentes, tem aparecido com intenções de voto muito superiores aos $1,29 \%$ que teve ao nível nacional.

Em Portugal, até recentemente, o voto antissistema e/ou populista com dimensão significativa e representação parlamentar era de esquerda, no Partido Comunista Português (PCP) e no Bloco de Esquerda (numa aceção abrangente de populismo), que conjuntamente obtinham cerca de 10 a $15 \%$ dos votos, com oscilações, nas eleições para a Assembleia da República.

O PCP, fundado em 1921 e com uma orientação marxista-leninista, pode ser visto como um partido tipicamente antissistema, com um vasto conjunto de críticas e propostas alternativas ao statu quo, com destaque para as orientações de política económica e o papel intervencionista do Estado. Já o Bloco de Esquerda, que tem centrado as suas críticas não tanto no sistema, mas nos seus problemas e nas dificuldades de vida de vários segmentos da população, resulta da refundação e fusão de pequenos partidos da denominada esquerda radical que incorporaram "novas" orientações associadas, por exemplo, às dimensões diversificadas da subordinação (género, etnia, orientação sexual, estrutura etária) que vão para lá da exploração assente no posicionamento dos indivíduos no sistema económico (classes sociais) e valorizam os aspetos identitários.

Nos seus discursos, ambos chamam a atenção para as grandes desigualdades existentes no país e invocam, por vezes, uma oposição entre as pessoas comuns (o povo, num sentido mais monolítico no caso do PCP e mais diversificado no que concerne ao $\mathrm{BE}$ ) e as classes dirigentes e os interesses plutocráticos, 0 que pode ser enquadrado no populismo diádico de esquerda. De resto, numa análise dos programas eleitorais dos principais partidos, entre 1995 e 2015, Lisi e Borghetto (2018) classificaram como populistas $29,4 \%$ dos parágrafos do programa do PCP e 17,9\% dos parágrafos do programa do Bloco, face a, respetivamente, $18,6 \%$ e $4,3 \%$ dos seus programas em 2015.

\section{Principais aspetos das propostas e do discurso eleitoral do Chega em 2019}

A identificação do Chega como um partido simultaneamente "nacional, conservador, liberal e personalista" pode ser problemática, pois alguns desses pilares são potencialmente conflituantes entre si. Por exemplo, no seu Programa Político 2019 (Chega, 2019), o partido define-se como simultaneamente liberal e conservador, o que pode ser contraditório. Só 
assim não é porque o Chega tem um programa económico ultraliberal e um programa identitário e de costumes conservador.

Relativamente às propostas, a dimensão liberal do Chega surge logo no início do seu Manifesto Político Fundador, no qual se diz que o partido "nasceu para reduzir o Estado às suas funções mínimas essenciais". Essa ideia é especificada no Programa Político de 2019, que defende, por exemplo, a extinção do Ministério da Educação para que o Estado tenha uma função apenas arbitral na educação, com a extensão dessa lógica ao ensino superior, para o qual se defende a privatização das universidades públicas. Similarmente, afirma-se que o estado "não deverá, idealmente, interferir como prestador de bens e serviços" de saúde e não deverá ter posições em empresas, sem que seja proposta qualquer estratégia económica.

Mas o que mais notoriamente tem distinguido o Chega dos restantes partidos, e que mais impacto mediático tem tido, é um discurso conservador e identitário que, ao mesmo tempo que sublinha o papel da Igreja Católica na estruturação das civilizações europeia e portuguesa e faz a apologia da identidade nacional supostamente una e estática, estigmatiza alguns grupos étnicos específicos (e.g. ciganos) com base na repetição de estereótipos.

Assim, no seu Manifesto Político Fundador, o partido tem como objetivo a "proibição de práticas políticas e religiosas que ofendam o ordenamento jurídico português e a raiz cultural europeia (mormente, o antissemitismo, as ideologias do género, a aplicação da Sharia, a excisão, os casamentos forçados de menores, a inibição da sua frequência da escolaridade mínima obrigatória, o racismo de qualquer natureza, entre outras práticas vigentes - e impunes - em comunidades que, para além de tudo, ainda se beneficiam de assistência do Estado, sem adimplemento das normas legais e gerais aplicáveis" (Chega, s/d). Para além de se misturarem, nesses exemplos, elementos de teor diverso e mesmo contraditório (a "ideoogia de género" e o "racismo de qualquer natureza", mas criticando o apoio do Estado a membros de algumas comunidades), fica implícita uma atitude estigmatizante e mesmo xenófoba em relação à comunidade cigana), que identifica desafios, mas não se preocupa em considerar tendências de transformação e desvaloriza políticas públicas capacitantes e direcionadas para a mudança social.

Paralelamente, e também na linha do que do tem sido o discurso da direita nacionalista noutros países europeus, o Chega afirma que "assentará prioritariamente a sua acção no combate ao 'politicamente correcto', à corrupção dos interesses, à censura institucionalizada, à imigração ilegal, às fragilidades no controlo das fronteiras e à impunidade crescente do crime organizado e violento".

André Ventura ascendeu a personalidade política nacional em 2017, quando, no âmbito da sua campanha como candidato, pelo PSD, à presidência (prefeito) do município de Loures fez declarações em que falava da impunidade na etnia cigana e dizia que esta vivia quase exclusivamente de subsídios do Estado. Referiu-se aos ciganos também como sendo frequentemente geradores de desacatos, algo que aparece em vários relatos da comunicação social (recorde-se, por exemplo, o ataque a um quartel de bombeiros em Borba, em 2019, por um grupo de elementos de etnia cigana local). ${ }^{9}$ Mais recentemente, a propósito da epidemia de Covid-19, propôs que fosse adotado um plano de confinamento específico para a comunidade cigana (porque 
supostamente havia violação sistemática das regras de confinamento impostas a toda a população por parte de segmentos da comunidade cigana, segundo foi relatado na comunicação social). ${ }^{10}$ Essa população está em Portugal há pelo menos cinco séculos, e a falta de reconhecimento social tem-se traduzido, no passado e no presente, em práticas e discursos de discriminação e racismo que claramente têm dificultado processos de aproximação entre os ciganos e a população maioritária lusa (Mendes, Magano e Candeias, 2014).

\section{A votação no Chega por municípios em 2019}

A votação no Chega nas eleições legislativas que decorreram em 6 de outubro de 2019 apresenta um padrão territorial surpreendente, a avaliar pelo que tem sido a geografia da tradicional divisão entre a esquerda e a direita herdada da fundação do regime democrático, em que a direita tem sido mais forte no Norte e a esquerda mais forte no Sul. Essa divisão resultou de, logo em 1975, o voto nos quatro partidos que se configuraram como estruturantes do sistema político-partidário democrático ter apresentado uma distribuição geográfica clara e que tendencialmente se tem mantido nas suas principais caraterísticas, apesar de elas terem começado a esbater-se nas eleições legislativas seguintes (Gaspar e André, 2018, pp. 160-164).

O voto no PSD apresentou logo de início uma forte dicotomia Norte-Sul, com algumas exceções no Norte do Alentejo e Algarve. A mesma dicotomia aconteceu com o voto no CDS-PP, mas com áreas de influência mais dispersas (pela menor dimensão desse partido) e maior dificuldade de penetração no Sul (Gaspar, André e Honório 2018 , pp. 102-108). O PS apresentou um padrão menos concentrado do que o dos outros três partidos, com implantações mais fortes no vale do Tejo e Algarve, e ainda em áreas industriais do Centro e do Norte Litoral, associadas também ao voto urbano, que tem sido uma das suas caraterísticas. Note-se que o Bloco de Esquerda, que se afirmou a desde 1999, apresenta também um voto concentrado nos centros urbanos. Por seu lado, historicamente o PCP tem tido o seu voto mais concentrado do que o dos outros três partidos referidos, essencialmente no Alentejo e nalguns concelhos da área metropolitana de Lisboa, mesmo num contexto em que tem sofrido uma tendência lenta e prolongada de perda de apoio eleitoral.

Ora, o mapa do quociente de localização da votação no Chega por concelho revela precisamente que é no Sul, até ao vale do Tejo (inclusive), que esse novo partido de direita populista apresenta votações acima da sua percentagem nacional (Figura 2). Essa mancha alarga-se aos municípios do litoral Oeste a norte de Lisboa, até próximo de Coimbra, e a alguns concelhos da Beira Interior, mas com valores inferiores aos registados mais a sul. Os municípios com maior incidência de votação no Chega encontram-se principalmente no Alentejo, sobretudo interior, na área metropolitana de Lisboa e Vale do Tejo e, ainda, no Algarve central e ocidental, padrão que até certo ponto coincide com o do Partido Comunista Português. Essa sobreposição com um partido que ideologicamente é muito o seu oposto levanta questões interessantes para análise, devendo sublinhar-se, antes de mais, um aspeto comum a esses dois partidos - ambos são vistos como fenómenos que refletem descontentamentos a que o sistema (e.g. partidos do, até 2015, designado "arco da governação") não tem dado respostas. 
Figura 2 - Quocientes de Localização dos votos válidos no Chega nas eleições para a Assembleia da República, 2019

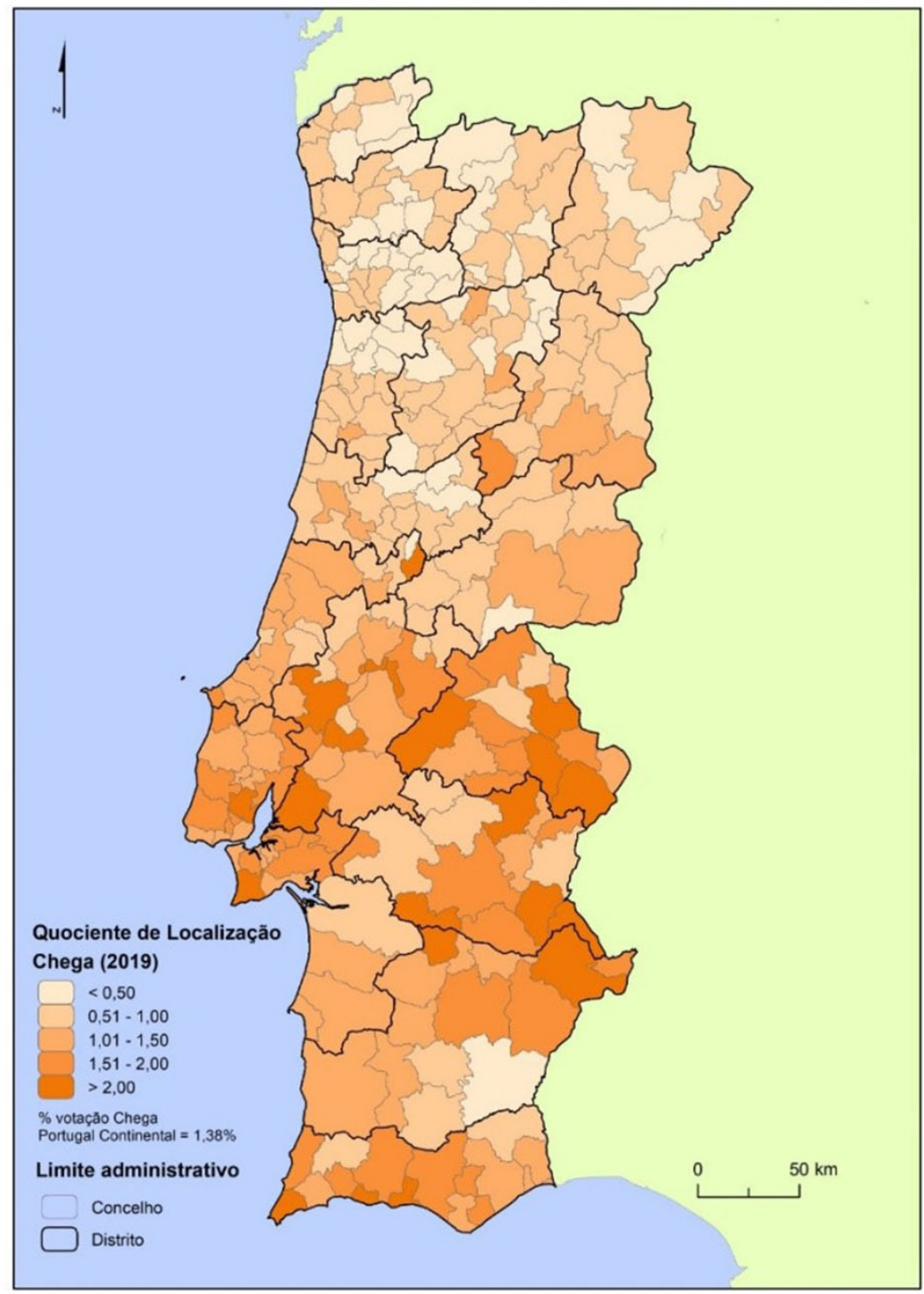


Além disso, o voto no PCP é habitualmente classificado como sendo "de protesto" (e também o voto no Bloco e nos pequenos partidos). Ora, isto tem ressonâncias óbvias com a geografia do descontentamento, assente na votação nos partidos de direita populista, com base em fenómenos claros de rejeição do sistema.

\section{Hipóteses explicativas para o padrão} municipal de voto no Chega: correlações lineares simples significativas e regressão múltipla com variáveis eleitorais, sociodemográficas e económicas

A correlação linear simples entre a votação percentual no Chega por município nas eleições legislativas de outubro de 2019 e um conjunto de variáveis eleitorais, sociodemográficas e económicas revelou valores do coeficiente de Pearson significativos para 13 delas (ver Quadro 3). Sem surpresa, a maior correlação encontrada foi com a votação no Partido Nacional Renovador $(0,56)$, um pequeno partido de direita nacionalista, com aspetos de extrema direita, estabelecido há vinte anos por via da refundação de um pequeno partido moribundo preexistente e que nunca conseguiu ter sucesso eleitoral nem eleger qualquer deputado ao Parlamento. Naturalmente, a semelhança programática entre ambos explica a forte correlação entre a territorialização das suas votações.

O que é surpreendente, tal como referido na análise do mapa da votação municipal, é a correlação relativamente elevada e positiva existente entre os padrões territoriais da votação no Chega e no PCP (que concorre sob a sigla CDU, por coligação com um pequeno

Quadro 3 - Correlações significativas com a votação municipal no Chega, Portugal Continental

\begin{tabular}{|l|c|}
\hline & $\begin{array}{c}\text { Correlação de } \\
\text { Pearson }\end{array}$ \\
\hline \% Partido Nacional Renovador-PNR (2019) & $0,555^{* *}$ \\
Tx. de variação na abstenção 2015-2019 & $0,533^{* *}$ \\
\% população com 15 e mais anos com ensino secundário (2011) & $0,470^{* *}$ \\
\% de população cigana & $0,457^{* *}$ \\
\% no partido PCP-PEV-2019 & $0,420^{* *}$ \\
\% população estrangeira (2019) & $0,342^{* *}$ \\
\hline \% Partido Social-Democrata-PSD (2019) & $-0,551^{* *}$ \\
\% população empregada setor secundário (2011) & $-0,481^{* *}$ \\
Tx. de variação do índice de envelhecimento (2011-2019) & $-0,466^{* *}$ \\
Tx. de variação do índice de envelhecimento (2015-2019) & $-0,410^{* *}$ \\
Tx. de variação do partido Bloco de Esquerda-BE (2015-2019) & $-0,43^{* *}$ \\
\% população com 15 e mais anos com até o 9o ano de escolaridade & $-0,397^{* *}$ \\
Tx. de variação do partido PS (2015-2019) & $-0,362^{* *}$ \\
\hline
\end{tabular}

** Correlação significativa ao nível 0,01 (bilateral).

Fonte: cálculos dos autores sobre dados do INE e do MAI. 
partido ecologista, o PEV). Esse coeficiente de correlação de 0,42 é mesmo o único positivo e forte com um partido importante no sistema político português.

Inversamente, a votação municipal no Chega, em 2019, apresenta uma correlação também relativamente forte, mas negativa $(-0,55)$, com a votação no PSD - isto é, onde mais se concentra o voto no PSD, menor foi a votação do Chega. E apresenta também correlações negativas relevantes com a variação 2015-2019 das votações no Bloco de Esquerda $(-0,43)$ e no PS $(-0,36)$. Mas aqui estamos no domínio do expectável: quanto maior a votação no Chega, menor o crescimento do Bloco e do PS, partidos cujos princípios são opostos aos do Chega.

Finalmente, ainda no domínio das variáveis eleitorais, foi encontrada uma correlação forte $(0,53)$ entre a variação da abstenção 2015-2019 e a votação no Chega, indiciando que o partido conseguiu maior penetração em municípios nos quais a percentagem de eleitores que desiste do sistema mais cresceu. Tendo em vista que a abstenção em Portugal pode frequentemente ser interpretada como um protesto passivo, no sentido de desistência em face do sistema, este é mais um indicador que associa a votação no Chega ao descontentamento dos eleitores e ao seu protesto, a par da correlação com a votação no PCP.

Entre as variáveis de âmbito sociodemográfico, a correlação mais forte $(0,47)$ regista-se com a percentagem de população que concluiu o ensino secundário, existindo inversamente uma correlação negativa com a percentagem de população que não concluiu mais do que o 9o ano. Considerando que na Europa o voto na direita populista tende a ser maior entre a população menos escolarizada, esses dados não têm uma interpretação óbvia. 0 mesmo se pode dizer sobre as importantes correlações negativas da votação no Chega por municípios e a variação do índice de envelhecimento entre 2011 e 2019 (-0,47\%) e entre 2015 e $2019(-0,41)$, pois os estudos que têm sido feitos em nível europeu indicam uma tendência de maior penetração desse tipo de partidos entre os eleitores mais velhos.

As correlações positivas da votação no Chega com a percentagem de estrangeiros residentes $(0,34)$ e, sobretudo, com a percentagem de população cigana $(0,46)$ vão no sentido previsível, levando-se em consideração o que se conhece para outros países. Este aspeto é particularmente significativo também devido à ênfase dada pelo líder do partido às questões ligadas a etnia cigana desde que se afirmou no espaço político-mediático português.

Das variáveis de natureza económica testadas, só a percentagem de população empregada no setor secundário apresenta uma correlação relevante $(-0,48)$ com a votação do Chega por concelho. Mas esta é uma variável importante, à luz do que já se sabe sobre a geografia do descontentamento na Europa, em que o voto na direita antissistema está associado ao declínio económico de longo prazo em regiões industriais.

Estes elementos permitem confirmar uma associação geográfica entre o voto no Chega e o descontentamento político-eleitoral, devido à sua sobreposição quer ao voto comunista quer à subida recente da abstenção. $E$ isto surge ligado à presença de população estrangeira e de população cigana portuguesa. ${ }^{11} \mathrm{Em}$ simultâneo, nos locais onde há mais indústria, a votação no Chega foi tendencialmente menor. 
A coincidência entre a maior penetração eleitoral do Chega e a presença de população estrangeira e de população cigana portuguesa vai ao encontro de alguns dados do Estudo Eleitoral Português de 2019 analisados por Magalhães (2020), segundo os quais uma esmagadora maioria de $88 \%$ dos eleitores do Chega considera que "as minorias deviam adaptar-se aos costumes e tradições de Portugal" (face a 63\% entre os votantes nos outros partidos em 2019); enquanto $62 \%$ defenderam que ter antepassados portugueses é "muito importante" para se ser "verdadeiramente português" (face a $36 \%$ entre os votantes nos outros partidos no mesmo ano). Mas essa coincidência deve ser interpretada com cautela, porque estamos perante um fenómeno muito recente e porque, no mesmo Estudo Eleitoral, 88\% dos votantes no Chega disseram que "os imigrantes são bons para a economia portuguesa" (face a $63 \%$ dos votantes nos outros partidos) e $25 \%$ disseram que os imigrantes fazem aumentar a criminalidade, menos do que os $28 \%$ de votantes nos outros partidos e bastante menos do que os $35 \%$ de abstencionistas que manifestaram a mesma opinião.

Como complemento à análise dos coeficientes de correlação de Pearson, o modelo de regressão múltipla construído para testar a associação da percentagem de votos obtidos pelo Chega às variáveis eleitorais, sociodemográficas e económicas, agora assumidas de forma conjunta, confirmou essencialmente o modo como algumas variáveis políticas e sociodemográficas já destacadas se combinam para explicar o padrão de votação municipal no Chega (Quadro 4).

\section{Quadro 4-Regressão múltipla passo a passo (resultados sucessivos) \\ (Variável dependente - Percentagem de votos no Chega nos municípios de Portugal Continental nas Legislativas de 2019)}

\begin{tabular}{|c|l|c|c|c|}
\hline $\begin{array}{c}\text { Modelo } \\
\text { (etapa) }\end{array}$ & \multicolumn{1}{|c|}{ Variáveis } & R & $\mathbf{R}^{2}$ & $\begin{array}{c}\mathbf{R}^{2} \\
\text { ajustado }\end{array}$ \\
\hline 1 & \% Partido Nacional Renovador - PNR (2019) & 0,555 & 0,308 & 0,305 \\
2 & Tx. variação da abstenção (2015-2019) & 0,670 & 0,448 & 0,444 \\
3 & Tx. variação Índice de Envelhecimento (2011-2019) & 0,703 & 0,495 & 0,489 \\
4 & \% Beneficiários(as) Rendimento Social de Inserção (2015) & 0,735 & 0,541 & 0,534 \\
5 & \% população com 15 e mais anos com ensino secundário (2011) & 0,760 & 0,577 & 0,569 \\
6 & Beneficiários(as) do Rendimento Social de Inserção (2015) & 0,785 & 0,616 & 0,608 \\
7 & Tx de variação população empregada no setor secundário (2001-2011 & 0,800 & 0,640 & 0,630 \\
\hline
\end{tabular}

Nota: de acordo com o teste $F$, todas as variáveis incluídas nessas etapas são significativas a um nível de 0,05. Fonte: cálculos dos autores sobre dados do INE e do MAI. 
Em termos políticos, continuam a destacar-se a percentagem de votos no PNR e a taxa de variação da abstenção, que se assumem como as variáveis com maior poder explicativo e que são incorporadas nos dois primeiros passos do modelo. Isto confirma a dimensão ideológica do voto (o nacionalismo populista de extrema direita partilhado com o PNR) e o elemento de protesto e descontentamento ante o sistema, que pode ser interpretado a partir do contributo da variação da percentagem de abstenção para explicar os resultados do Chega. Note-se que a ausência de outras variáveis políticas no conjunto das retidas como mais significativas neste modelo de caráter multivariado (com destaque para as percentagens de votos no PSD e no PCP-PEV, ${ }^{12}$ que registam coeficientes de correlação relativamente elevados, embora de sinais diferentes, com a percentagem de votos obtida pelo Chega em 2019), justifica maior refinamento na análise dessas ligações simples, algo que valerá a pena efetuar no futuro com o apoio de mais informação sobre efetivas transferências de voto. Mesmo assim, vale a pena desde já alertar para o facto de as correlações entre as percentagens de votos obtidas por esses dois partidos em 2019 e a variação da percentagem de abstenção entre 2015 e 2019 serem mais fortes (embora com sentido positivo no caso do PCP-PEV e negativo no caso do PSD) do que as correlações entre as supracitadas percentagens e a percentagem de votação do Chega no mesmo ato eleitoral. Como a variável correspondente à abstenção é uma das mais fortes do modelo, a sua redundância com as percentagens de votos no PSD e no PCP/PEV não só ajuda a explicar a redução do significado estatístico destas na regressão múltipla, como chama a atenção para que eventuais ligações ou transferências de voto entre esses eleitorados impliquem uma análise do papel da abstenção no processo.

Relativamente às dimensões sociodemográfica e económica, os resultados do modelo confirmam a aparente originalidade do perfil dos votantes do Chega em face do que tem sido detetado em estudos efetuados para partidos semelhantes em outros países europeus (eleitores menos envelhecidos e com qualificações algo mais elevadas no caso português), embora o facto de se tratar de uma "votação pioneira" (foi a primeira vez que o partido se apresentou a eleições) justifique prudência nessa análise comparativa. Ainda no âmbito social, o modelo incorpora, ainda que de forma indireta (por via das variáveis associadas ao Rendimento Social de Inserção - RSI), a proporção de população cigana ${ }^{13} \mathrm{e}$, de forma mais alargada, a proporção de população em situação de dependência e forte desvantagem social no quadro combinado de explicações para o voto no Chega. Efetivamente, um discurso de caráter xenófobo particularmente direcionado para o grupo étnico cigano, que, como vimos, veicula sistematicamente a associação deste à subsidiodependência, parece encontrar eco junto dos eleitores que residem em municípios onde a população que recebe RSI é mais significativa, sendo fácil associar esta à etnia cigana, mesmo que constitua uma percentagem minoritária do conjunto de beneficiários.

A metade sul de Portugal enquanto paisagem eleitoral preferencial do Chega - contributos breves para uma interpretação

Quando consideramos as correlações entre a votação no Chega por municípios e as variáveis analisadas apenas relativamente aos municípios da metade sul de Portugal, fica claro que 
perdem peso as correlações significativas com variáveis de natureza eleitoral e ganham peso as correlações significativas com variáveis socioeconómicas (ver Quadro 5). Nessa parte do país em que o partido conseguiu maior votação, deixa de ser importante a correlação com o voto comunista e é menos forte a correlação com o voto no PNR. A correlação com a presença de população cigana é ainda mais forte do que para o total do país, mas deixa de ser relevante a correlação com a presença de população estrangeira.

Simultaneamente, ganham peso as variáveis mais ligadas a dificuldades económicas, passando a haver correlações significativas com a percentagem de beneficiários do Rendimento Social de Inserção (população pobre) e de população desempregada, mantendo-se presente a correlação negativa com o emprego industrial. Além disso, deixam de aparecer correlações significativas com os níveis de instrução e surgem com a população jovem (positiva) e com o índice de envelhecimento (negativa).

Essas particularidades dos resultados do Chega nas áreas em que obteve votações mais expressivas parecem indicar um maior peso dos problemas económicos nas motivações dos eleitores, mas tais problemas podem ser interpretados como algo que está ligado à presença de populações de imigração recente ou ciganas, como é veiculado pelo discurso populista triádico de direita. De resto, como referimos anteriormente, o estereótipo que associa o Rendimento Social de Inserção a pessoas de etnia cigana evidencia precisamente esse tipo de ligações.

A regressão múltipla aplicada às mesmas variáveis e considerando a percentagem de votos no Chega como variável dependente, para o

Quadro 5 - Correlações significativas com a votação municipal no Chega nos municípios do sul de Portugal

\begin{tabular}{|l|c|}
\hline & $\begin{array}{c}\text { Correlação de } \\
\text { Pearson }\end{array}$ \\
\hline \% de população cigana & $0,533^{* *}$ \\
\% Beneficiários(as) Rendimento Social de Inserção (2019) & $0,472^{* *}$ \\
\% Beneficiários(as) Rendimento Social de Inserção (2015) & $0,439^{* *}$ \\
\% População desempregada (2019) & $0,375^{* *}$ \\
Tx. de variação PAN (2015-2019) & $0,361^{* *}$ \\
\% Abstenção (2019) & $0,354^{* *}$ \\
\% população jovem 15-29 anos (2011) & $0,350^{* *}$ \\
\% Partido Nacional Renovador-PNR (2019) & $0,349^{* *}$ \\
\hline \% população empregada setor secundário (2011) & $-0,385^{* *}$ \\
Índice de envelhecimento (2019) & $-0,351^{* *}$ \\
\hline \multicolumn{2}{|c|}{ \% votos no Chega (2019): Variável dependente } \\
\hline
\end{tabular}

** Correlação significativa ao nível 0,01 (bilateral).

Fonte: cálculos dos autores sobre dados do INE e do MAI. 
conjunto dos municípios da metade sul do país (Quadro 6), confirma o maior peso das variáveis relacionadas às dificuldades económicas, com destaque para o RSI, bem como a associação ao emprego industrial, que tem na sua base um princípio inverso (quanto maior este, menor a percentagem de votos no Chega).

Contudo, nesse modelo multivariado, as variáveis eleitorais dão contributos interessantes, mantendo-se a percentagem de votos no PNR como o indicador mais forte, se bem que perdendo significado diante do modelo que considera todos os municípios do país. Adicionalmente, o modelo integra, como elementos da explicação combinada para a percentagem de votos obtidos pelo Chega nos municípios da metade sul de Portugal, as taxas de variação (2015-2019) das votações em dois partidos relativamente jovens (Bloco de Esquerda e PAN) que podem ser posicionados na área do protesto e que aparecem frequentemente associados a direitos particulares (e.g. de grupos sociais específicos; dos animais). Note-se que as correlações lineares simples de Pearson entre as variações na percentagem de cada um desses partidos e a percentagem do Chega têm sentido distinto, verificando-se um valor negativo no caso do BE (os padrões geográficos têm elementos de antítese um em relação ao outro) e positivo no que respeita ao PAN (os padrões apresentam elementos de sobreposição). Finalmente, a percentagem de votos no PCP-PEV entra como a última variável independente do modelo, confirmando, para a área do país onde o Partido Comunista tem tradicionalmente maior implantação, alguma proximidade ao padrão de votação do Chega, se bem que isto tenha de ser analisado em ligação com outras variáveis e considerando a redução na correlação de Pearson entre esses dois indicadores, quando comparada com o valor obtido para o conjunto dos municípios do país.

Quadro 6 - Regressão múltipla passo a passo (resultados sucessivos) municípios do sul de Portugal

(Variável dependente - Percentagem de votos no Chega nas Legislativas de 2019)

\begin{tabular}{|c|l|c|c|c|}
\hline $\begin{array}{c}\text { Modelo } \\
\text { (etapa) }\end{array}$ & \multicolumn{1}{|c|}{ Variáveis } & R & $\mathbf{R}^{2}$ & $\begin{array}{c}\mathbf{R}^{2} \\
\text { ajustado }\end{array}$ \\
\hline 1 & \% Beneficiários(as) Rendimento Social de Inserção (2019) & 0,472 & 0,223 & 0,215 \\
2 & \% Partido Nacional Renovador-PNR (2019) & 0,632 & 0,400 & 0,389 \\
3 & Tx. de variação do partido Bloco de Esquerda-BE (2015-2019) & 0,684 & 0,468 & 0,453 \\
4 & \% população empregada setor secundário (2011) & 0,707 & 0,500 & 0,481 \\
5 & Beneficiários(as) do Rendimento Social de Inserção (2019) & 0,726 & 0,526 & 0,504 \\
6 & Tx. de variação PAN (2015-2019) & 0,740 & 0,547 & 0,521 \\
7 & \% no partido PCP-PEV-2019 & 0,753 & 0,566 & 0,536 \\
\hline
\end{tabular}

Nota: de acordo com o teste $F$, todas as variáveis incluídas nessas etapas são significativas a um nível de 0,05. Fonte: cálculos dos autores sobre dados do INE e do MAI. 


\section{Conclusão}

O Chega começou a afirmar-se no espaço político-partidário português com algumas caraterísticas específicas em face de fenómenos semelhantes noutros países europeus. Uma dessas caraterísticas é que se o seu programa político é radicalmente neoliberal do ponto de vista económico e aparece marcado por contradições relativamente à inserção da economia portuguesa em arranjos internacionais potencialmente prejudiciais a partes da população. Por exemplo, no que respeita ao projeto Europeu, os apoios explícitos existentes em documentos do partido e declarados pelo seu líder são contraditados por críticas ao controlo da economia nacional por parte dos países mais avançados da UE que, entre outras coisas, implicariam uma ação de recuperação da autonomia na emissão de moeda (Marchi, 2020).

0 eixo discursivo do Chega em que mais se identifica a semelhança com essa nova direita nacionalista é o identitário, sendo clara uma forte preocupação conservadora. Essa dimensão identitária, a par da dicotomia entre o povo e uma classe dirigente tida como oligárquica, e entre os portugueses "de origem" e os estrangeiros e membros de grupos étnicos não lusos (em particular a população cigana), faz do Chega um exemplo do populismo triádico de direita que tem crescido na Europa nos anos mais recentes.

A geografia eleitoral do Chega, pelo menos num primeiro momento, que corresponde às eleições legislativas de outubro de 2019, revelou-se contraintuitiva em relação ao que tem sido a implantação territorial dos partidos de direita em Portugal, pois a sua maior penetração ocorreu em áreas (metade sul de Portugal) onde historicamente tem mais força o voto de esquerda, sobretudo o comunista.

A correlação positiva da votação no Chega por municípios com a do PCP (representado pela CDU) e, principalmente, com o crescimento da abstenção confirma a ideia de os seus eleitores estarem sobretudo em grupos socioeconómicos descontentes, ou ressentidos, com as dificuldades do dia-a-dia e com o sistema político-partidário, tal como tem acontecido noutros países europeus. Esse descontentamento, que também tira partido de alguma desmobilização eleitoral noutros campos, tanto à direita (caso do CDS, partido cristão e conservador), como à esquerda (por exemplo, na área do P(P), aparece também relacionado com questões identitárias, o que transparece através das fortes correlações com a percentagem de população estrangeira e, sobretudo, cigana em cada concelho.

Note-se que as variáveis de natureza sociodemográfica mais correlacionadas com a votação no Chega apontam para uma sociologia dos seus eleitores um pouco atípica ante o que tem sido encontrado nos estudos sobre esse fenómeno na generalidade dos países europeus, porque existem correlações negativas com a população menos instruída e com o aumento recente do índice de envelhecimento. Essa sociologia atípica é corroborada pelo modelo de regressão múltipla aplicado ao conjunto de variáveis eleitorais, sociais e económicas utilizado para explicar a percentagem de votação no Chega nos municípios portugueses.

Sendo menos óbvia, encontra-se também alguma relação entre o padrão territorial da votação no Chega e variáveis ligadas à falta 
de dinamismo económico. Isto decorre de se ter detetado uma menor penetração deste partido nas áreas onde há mais emprego na indústria e uma presença mais significativa nos municípios com maior percentagem de população que recebe Rendimento Social de Inserção, situação mais clara no caso da metade sul do país, onde o Chega apresenta maiores votações.

Estes resultados mostram claramente que a geografia do voto no Chega se insere naquilo a que, na Europa, se tem chamado de geografia do descontentamento, ou ressentimento, com uma base eleitoral que responde ao mesmo tipo de motivações. Os votantes neste novo partido apresentam caraterísticas sociodemográficas um pouco atípicas no contexto europeu, mas a respetiva distribuição territorial tem uma significativa correspondência com a de variáveis caraterísticas de preocupações identitárias e, em menor grau, de dificuldades económicas.

Note-se que essa tentativa de esboçar uma geografia do descontentamento em Portugal decorreu quando o fenómeno de uma possível revolta eleitoral associada aos problemas de setores populacionais com dimensão importante era ainda embrionário, tendo começado a tornar-se visível justamente nas eleições cujos resultados aqui analisámos. Considerando que todo o contexto leva a supor um possível crescimento rápido do Chega, o padrão territorial da sua votação e algumas caraterísticas da sua base de eleitores poderão também sofrer alterações em próximas eleições.

Por último, há que referir duas limitações da análise que justificam uma exploração em trabalhos posteriores. Em primeiro lugar, a não inclusão de variáveis socioprofissionais, designadamente considerando situações na profissão, desconsidera uma dimensão complementar potencialmente importante para explicar os padrões geográficos de voto detetados. Em segundo lugar, a diversidade interna de muitos concelhos em termos demográficos, sociais e económicos, com destaque para os maiores e mais urbanizados, traduz-se, provavelmente, em valores de correlação mais baixos entre esse tipo de variáveis e os resultados eleitorais do Chega. A obtenção de resultados mais claros e robustos poderia partir de um tratamento da informação em nível submunicipal (freguesias), pelo menos para uma amostra de municípios onde o Chega obteve resultados mais expressivos. Infelizmente, porque sentimos necessidade de fazer, inicialmente, uma abordagem que conjuga componentes mais gerais com uma escala de análise um pouco maior (o município), já não houve espaço para efetuar o aprofundamento no nível da freguesia, que terá de ficar para um próximo trabalho. 


\section{[I] https://orcid.org/0000-0003-3206-5522}

Universidade de Lisboa, Instituto de Ciências Sociais e Centro de Estudos Geográficos. Lisboa, Portugal.

paulo.madeira@campus.ul.pt

\section{[II] https://orcid.org/0000-0001-5935-9390}

Universidade de Lisboa, Instituto de Ciências Sociais e Centro de Estudos Geográficos. Lisboa, Portugal.

katielle@campus.ul.pt

\section{[III] https://orcid.org/0000-0002-0976-044X}

Universidade de Lisboa, Instituto de Geografia e Ordenamento do Território, Centro de Estudos Geográficos. Lisboa, Portugal.

jmalheiros@campus.ul.pt

\section{Nota de agradecimento}

Os autores agradecem a Diogo Gaspar Silva pelo apoio técnico no tratamento da informação estatística e confeç̧ão do mapa. Também são gratos ao Centro de Estudos Geográficos do Instituto de Geografia e Ordenamento do Território da Universidade de Lisboa, financiado pela Fundação para a Ciência e a Tecnologia (FCT, I.P.) no âmbito das subvenções "UIDB/ GEO/00295/2020" e "UIDP/GEO/00295/2020", pelo apoio financeiro para a tradução do manuscrito para o inglês. Finalmente, os autores expressam reconhecimento aos revisores anónimos pelos valiosos comentários e sugestões, embora o conteúdo do artigo e as ideias nele expressas sejam da inteira responsabilidade dos seus autores.

\section{Notas}

(1) Embora o Chega tenha sido a primeira força política dessa área ideológica a eleger um deputado, esse tipo de discurso e orientação está também na matriz do Partido Nacional Renovador (PNR), uma pequena força política que concorre às eleições parlamentares desde 1999, apesar de nunca ter conseguido eleger qualquer parlamentar.

(2) Disponível em: http://www.resultadoseleitorais.azores.gov.pt/Resultados.aspx. Acesso em: 14 dez 2020.

(3) No original: "More concretely, we define populism as a thin-centered ideology."

(4) Por razões de simplificação da análise, consideraram-se apenas os 278 municípios de Portugal continental, o que implicou excluir os 30 municípios das regiões autónomas insulares atlânticas dos Açores e da Madeira.

(5) Concelho é um sinónimo de município. 
(6) Os QLs resultam da divisão da percentagem de votos obtidos pelo Chega em cada município pela percentagem de votos que conseguiu em nível nacional. Isto permite identificar o nível de sobrerrepresentação (valores superiores à unidade) ou sub-representação (valores inferiores à unidade) das votações registradas em cada município.

(7) O PSD e o CDS, que governaram Portugal na legislatura anterior (2011-2015), concorreram coligados nas eleições de 2015 sob a designação "Portugal à Frente" e obtiveram o maior número de votos, o que significou, no quadro dos princípios da política portuguesa, que o líder dessa coligação foi o primeiro a ser chamado para formar governo.

(8) Em Portugal, os distritos são unidades territoriais de escala sub-regional para fins administrativos.

(9) Reportagem com André Ventura (Bugalho, 2017).

(10) Reportagem com André Ventura (Banha, 2020).

(11) Residem em Portugal alguns ciganos estrangeiros, sobretudo de nacionalidade romena, mas o seu número é muito pouco significativo quando comparado com a população cigana portuguesa.

(12) Note-se que o coeficiente de correlação de Pearson resultante da associação entre as percentagens obtidas por estes dois partidos a nível municipal nas eleições legislativas de 2019 é bastante elevado, embora de sinal negativo $(-0,791)$. Isto aponta, desde logo, para alguma redundância entre os dois padrões.

(13) Note-se que a variável referente à população cigana não pode ser incorporada nesses modelos de regressão porque, como vimos, apenas existem dados para 113 unidades de análise (concelhos) e não para as 278 que são cobertas pelas restantes variáveis.

\section{Referências}

BANHA, A. T. (2020). Reportagem com André Ventura: "Chega quer plano de confinamento 'específico' para comunidade cigana”. Jornal / online, 4/5. Disponível em: https://ionline.sapo.pt/ artigo/695215/chega-quer-plano-de-confinamento-especifico-para-comunidade-cigana. Acesso em: 27 ago 2020.

BONIKOWSKI, B. (2017). Ethno-nationalist populism and the mobilization of collective resentment. The British Journal of Sociology, v. 68, n. S1.

BUGALHO, S. (2017). Reportagem com André Ventura: "Os ciganos vivem quase exclusivamente de subsídios do Estado". Jornal/ online, 17/1. Disponível em: https://ionline.sapo.pt/artigo/572563/ andre-ventura-os-ciganos-vivem-quase-exclusivamente-de-subsidios-do-estado. Acesso em: 27 ago 2020.

CHEGA (2019). Programa Político 2019. Disponível em: https://partidochega.pt/programapolitico-2019/. Acesso em: 27 ago 2020.

CHEGA (s/d). Manifesto Político Fundador. Disponível em: https://partidochega.pt/manifesto/. Acesso em: 19 ago 2020. 
DIÁRIO DE NOTíCIAS (2019). Ciganos, imigrantes e prisões. O que diz André Ventura. Disponível em: https://www.dn.pt/poder/ciganos-imigrantes-e-prisoes-o-que-diz-andre-ventura-11379814. html. Acesso em: 19 ago 2020.

DIJKSTRA, L.; POELMAN, H.; RODRÍGUEZ-POSE, A. (2019). The geography of EU discontent. Regional Studies, v. 54, n. 6, pp. 737-753. DOI: 10.1080/00343404.2019.1654603.

FERRÃO, J. (2019). "Para uma geografia com todos os lugares: reflexões a partir do caso europeu". In: FERREIRA, A. et al. Produção do espaço - Emancipação social, o comum e a "verdadeira democracia". Rio de Janeiro, Consequência Editora.

FREIRE, A. (2001). Mudança eleitoral em Portugal: clivagens, economia e voto em eleições legislativas, 1983-1999. Oeiras, Celta.

(2017). Para lá da "Geringonça": o governo de esquerdas em Portugal e na Europa. Lisboa, Contraponto.

FREIRE, A. (2019a). Populismo (I): Um Programa Analítico. A Vaca Voadora, 23 de outubro. Disponível em: https://avacavoadora.pt/populismo-i-um-programa-analitico/. Acesso em: 16 dez 2020.

(2019b). Populismo (II): Um Programa Político para a Esquerda? A Vaca Voadora, 28 de novembro. Disponível em: https://avacavoadora.pt/populismo-i-um-programa-analitico/. Acesso em: 16 dez 2020.

FUKUYAMA, F. (2019). Francis Fukuyama: políticos conservadores à la Trump não sabem governar. Disponível em: https://veja.abril.com.br/politica/francis-fukuyama-politicos-conservadores-ala-trump-nao-sabem-governar/. Acesso em: 10 jul 2020.

GASPAR, J.; ANDRÉ, I.; HONÓRIO, F. (2018). “As eleições para a Assembleia da República: 1979-1983. Estudo de Geografia Eleitoral”. In: ESTEVENS, A.; CARMO, A. Isabel André, uma geógrafa inquieta: textos escolhidos. Lisboa, Centro de Estudos Geográficos, Instituto de Geografia e Ordenamento do Território, Universidade de Lisboa.

GASPAR, J.; ANDRÉ, I. (2018). “Portugal - Geografia Eleitoral: 1975-1987”. In: ESTEVENS, A.; CARMO, A. Isabel André, uma geógrafa inquieta: textos escolhidos. Lisboa, Centro de Estudos Geográficos, Instituto de Geografia e Ordenamento do Território, Universidade de Lisboa.

GORDON, I. (2018). In what sense left behind by globalisation? Looking for a less reductionist geography of the populist surge in Europe. Cambridge Journal of Regions, Economy and Society, v. 11, pp. 95-113. DOI: 10.1093/cjres/rsx028.

GUILLUY, C. (2014). La France périphérique - Comment on a sacrifié les classes populaires. Champs actuel. Paris, Flammarion.

JUDIS, J. B. (2016). The Populist Explosion: How the Great Recession Transformed American and European Politics. Nova York, Columbia Global Reports.

KING, G. (1997). "Qualitative Overview”. In: KING, G. A solution to the ecological inference problem. Reconstructing individual behavior from aggregate data. Princeton, Princeton University Press.

LISI, M.; LLAMAZARES, I.; TSAKATIKA, M. (2019). Economic crisis and the variety of populist response: evidence from Greece, Portugal and Spain. West European Politics, v. 42, n. 6, pp. 1284-1309. DOI: 10.1080/01402382.2019.1596695. 
LISI, M.; BORGHETTO, E. (2018). Populism, Blame Shifting and the Crisis: Discourse Strategies in Portuguese Political Parties. South European Society and Politics, v. 23, n. 4, pp. 405-427. DOI: 10.1080/13608746.2018.1558606.

MADEIRA, P. M. (2019). Dinâmicas regionais e políticas de desenvolvimento territorial: um olhar cruzado entre a UE e o Brasil. Tese de doutorado. Lisboa, Universidade de Lisboa.

MAGALHÃES, P. (2020). O que pensam os que votaram no Chega? Margens de Erro, 22 de fevereiro. Disponível em: https://www.pedro-magalhaes.org/o-que-pensam-os-que-votaram-no-chega/. Acesso em: 23 dez 2020.

MALHEIROS, J. (2012). "Framing the Iberian model of labour migration. Employment exploitation, de facto deregulation and formal compensation". In: OKOLSKI, M. (ed.). European Immigrations Trends, Structures and Policy Implications. Amesterdã, Amsterdam University Press, pp. 159-178.

MARCHI, R. (2020). A Nova Direita Anti-Sistema. O caso do Chega. Lisboa, Almedina.

MARTIN, R.; TYLER, P.; STORPER, M.; EVENHUIS, E.; GLASMEIER, A. (2018). Globalization at a critical conjuncture? Cambridge Journal of Regions, Economy and Society, v. 11, n. 1, pp. 3-16. DOI:10.1093/cjres/rsy002.

MCCANN, P. (2019). Perceptions of regional inequality and the geography of discontent: insights from the UK. Regional Studies, v. 54, n. 2, pp. 256-267. DOI: 10.1080/00343404.2019.1619928.

MENDES, M.; MAGANO, O.; CANDEIAS, P. (orgs.) (2014). Estudo Nacional sobre as Comunidades Ciganas. Lisboa, Alto Comissariado para as Migrações (ACM, IP).

MOUFFE, C. (2018). For a left populism. Londres/Nova York, Verso.

MUDDE, C. (2004). The Populist Zeitgeist. Government and Opposition, v. 39, n. 4, pp. 541-563. DOI: 10.1111/j.1477-7053.2004.00135.x.

MUDDE, C.; KALTWASSER, C. R. (2017). Populism - A very short introduction. Oxford, Oxford University Press.

RODRÍGUEZ-POSE, A. (2018). The revenge of the places that don't matter (and what to do about it). Cambridge Journal of Regions, Economy and Society, v. 11, n. 1, pp. 189-209. Doi: 10.1093/cjres/ rsx024.

SASSEN, S. (2014). Expulsions - Brutality and Complexity in th Global Economy. Cambridge (MA) e Londres, The Belknap Press.

SGMAI (2019). Históricodaseleições.Disponívelem:https://www.sg.mai.gov.pt/AdministracaoEleitoral/ EleicoesReferendos/HistoricoEleicoes/Paginas/default.aspx?FirtOpen=1. Data de acesso: 3 ago 2020.

TODD, E. (2020). Les Luttes de classes en France au XXIe siécle. Paris, Éditions du Seuil.

Texto recebido em 31/ago/2020

Texto aprovado em 10/dez/2020 